\title{
Preliminary Evidence for Using Statistical Classification of Vibration Waveforms as an Initial Decay Detection Tool
}

\author{
Anthony N. Mucciardi, Christoper J. Luley, and Kevin H. Gormally
}

\begin{abstract}
Arborists commonly use sounding during an initial evaluation of urban trees to determine the presence of advanced decay and hollows. Striking the trunk with a mallet produces stress waves that propagate through the wood and, in turn, generate characteristic audible sounds. Successful application of this procedure, however, requires subjective evaluation of the sonic variations that result from different wood species and densities, and various ambient noise conditions. Therefore, a statistical classification approach was developed for automatically identifying decay from stress waves captured using an accelerometer probe that is less subjective and more reproducible than an operator-in-the-loop approach. The classification algorithms were designed to detect the presence of decay from aberrant characteristics of the vibration waveform and do not rely on sonic velocity changes commonly used in most sonic testing for decay. The approach was tested in a preliminary study on 36 segmented trunk samples representing a wide range of typical urban tree species and decay types. The classifier successfully identified the decay status of $83 \%$ of the samples independent of species and trunk diameter. The results of this feasibility study cannot be transferred to real world tree inspection without additional testing on standing trees, but do demonstrate the potential of using accelerometers supplemented with a statistical classifier to support an initial assessment of decay in urban trees by an arborist.

Key Words. Accelerometer; Decay Detection; Feature Extraction; Pattern Classification; Sounding; Stress Waves; Urban Trees; Vibration Waves Wood Decay.
\end{abstract}

Sounding is a practical and widely accepted field technique for initially establishing the presence or absence of internal decay in trees, including those in urban settings (Boyce 1961; Mattheck and Breloer 1994) and wood in service (Zabel and Morrell 1992). An arborist evaluates the soundness of a tree by striking the trunk with a mallet, hammer, or other solid object and analyzing the resulting sounds for abnormal characteristics associated with decay. The acoustic structure of the sound is determined by the propagation of the vibration waves though the volume of sound wood, decayed wood, or any internal voids, such as those created by enzymatic degradation by fungi.

The effectiveness of sounding as a preliminary evaluation tool has been discussed (Boyce 1961), but no research literature appears to address the subject with statistical rigor. However, it is clear that sounding is a learned skill and its effectiveness is therefore subject to the experience of the evaluator and, in particular, his/her ability to adapt to the variability introduced when evaluating different tree specimens, including the bark thickness, trunk diameter, and amount of decay.

Alternatively, aberrant sonic wave propagation can be automatically detected using a noninvasive sensor system. The authors propose a novel accelerometer-based system that is inspired by an arborist's approach to sounding analysis. An accelerometer is a precise electro-mechanical analog to the human ear; it is a small sensor that measures reverberations of the trunk surface as the rate of change of the surface's movement (velocity) with respect to time. The sensor picks up low amplitude vibrations, amplifies them, and converts them into a digital signal for further processing. Compared to classical sounding, analytical classification of waveforms recorded by an accelerometer can offer arborists a less subjective and more reproducible noninvasive method of initially detecting decay in urban trees. Data recorded by the accelerometer is insensitive to ambient noise, operates at a much higher sensitivity to frequencies of interest than the human ear, and does not lose its frequency discrimination over time like the human operator.

Recent research has introduced numerous instrumented systems for nondestructive decay detection that aim to improve the accuracy of preliminary tree health evaluations and reduce the chance of human errors (Mattheck and Bethge 1993; Bucur 2003; Nicolotti 2003; Axmon et al. 2004; Gilbert and Smiley 2004; Wang et al. 2008; Brashawet al. 2009). These systems employ methods that range from relatively simple stress wave and ultrasonic single-path timing calculators to more advanced tomographic reconstruction algorithms based on multipath propagation measurements. These noninvasive detection methods can accurately reveal the general location and magnitude of defects and fine resolution of the decay can then be achieved using microdrilling (Wang et al. 2008).

Single-path timing methods (Mattheck and Bethge 1993; Wang et al. 2004; Kazemi-Najafi et al. 2009) detect decay simply by comparing a modeled transmission time along a single path through transverse sections of the wood to the observed time. The benefit of these systems' simplicity, however, is offset by their limited capabilities for decay detection. Stress wave velocity varies substantially across tree samples, even intact trees and a standard reference velocity are not readily available for the data interpretation (Wang et al. 2005; Wang and Allison 2008).

These concepts have been extended to more extensive, complex, and expensive multipath systems based on a ring of sensors. Rinn (1999) was the first to publish on multipath tomography using chains of electronically independent sources 
that used speed, pulse height, and other wave properties in combination with electrical impedance. Other investigators have since reported on ring of sensor-based methods (Nicolotti et al. 2003; Gilbert and Smiley 2004; Bucur 2005; Wang et al. 2005; Wang et al. 2008). The sonic tomography instruments have shown increased resolution of internal defects at the expense of operational simplicity and increased costs.

The Axmon et al. (2004) multipath system represents somewhat of a balance between the simple single-path timing instruments and the more complex tomography systems. Although the Axmon et al. instrument required additional equipment (using a ring of accelerometer sensors), it also incorporated a relatively simple decay detection logic based on frequency and surface wave propagation velocity. The system successfully identified decay in living stands of Picea abies with an accuracy of approximately $74 \%$. These promising results were limited to this single species, however, and the authors concluded that their models would likely have to be recalibrated for each new stand.

This research study was conducted to determine the feasibility of using a relatively simple electro-mechanical instrument for decay detection based on statistical classification of a stress-induced sonic waveform recorded from a single accelerometer sensor, as opposed to velocity-based stress wave timing. This system extracted statistical features that were similar to the acoustic cues used to train human operators during a sounding evaluation. Like the aforementioned nondestructive detection instruments, it would be invariant to an operator's experience level, so that different operators would obtain the same results. Unlike the multipath measurement instruments, however, this system would have the benefit of requiring only a relatively simple and inexpensive set of hardware components, as well as generalizing to detect decay across a wide variety of urban tree species without repeated calibration.

The theoretical basis for measuring characteristic acoustic structures with statistical features and classifying the contents of a trunk based on those feature values is built on the basic principles of vibration wave propagation and psychoacoustic research. When a hammer strikes the trunk, a stress wave is generated that propagates through the wood matrix at a velocity proportional to the square root of Young's modulus, which depends on the physical properties of the wood. The stress wave moves through the medium by alternating pulses of pressure waves that travel parallel to the trunk surface with a wave period (wavelength) determined by the wave's velocity. Internal discontinuities of the medium alter the velocity and amplitude of the wave. When it reaches the surface and causes it to vibrate, the vibrations generate pressure waves in the surrounding air that are perceived as sound when these airborne pressure waves strike an eardrum. The perceived pitch of these sounds is dependent upon the trunk reverberations and, thus, by its internal condition. Due to the mass of the trunk, the frequency of the pitch falls in the normal audible range (approximately 50 to $4,000 \mathrm{~Hz}$ ).

Although psychoacoustic research does not specifically discuss wood decay sounds, it has shown that the human brain can distinguish many other complex natural sounds (Howard 1977; Howard and Ballas 1980; Ballas 1993; Miller 1994), including footfalls ( $\mathrm{Li}$ et al. 1991), slamming doors (Fowler and Rosenblum 1990), clapping hands (Repp 1987), and breaking bottles (Warren and Verbrugge 1984). Notably, Freed (1990) found that there are acoustic differences between percussive events like mallet strikes, and Lufti (2001) found that listeners can develop strategies for distinguishing solid and hollow metal and wooden bars. The sounds considered in these studies contained sufficient information to allow identification of complex source attributes (analogous to decay), and moreover, that listeners are capable of performing these identifications with limited variation in other source attributes (analogous to diameter and species).

The authors studied various statistical features to determine which combination comprised sufficient information to successfully distinguish sounds from decayed versus non-decayed tree samples. As in traditional engineering literature, features that described various aspects of the waveform's acoustic structure were explored (Stearns 1976; Shin and Kil 1996; Vapnik 1998; Wellman and Srour 1999).

To demonstrate the feasibility of using an acoustic waveform classification system to detect decay across a range of urban tree species, the study authors assembled a test bed consisting of a variety of recently cut tree sections across a wide range of commonly found urban tree species, trunk diameter, and internal conditions (solid, advanced decay, and hollow). A simple accelerometer-based data collection system and applied signal processing, waveform feature extraction, and pattern classification algorithms were configured to the test bed samples to estimate the classifier's performance.

\section{MATERIALS AND METHODS}

\section{Sample Selection}

Twenty felled urban trees were collected in Maryland, U.S. The trunks were further divided with a chain saw if visual assessment indicated that different levels of decay were present. Although limited vibration differences may result from using felled trunk segments instead of standing trees, the authors had to rely on these segments as the only available test data, as have similar studies (Nicolotti et al. 2003; Wang et al. 2005). The final data set consisted of 36 sections of 12 different tree species, a much wider range of species than similar studies (Axmon et al. 2004; Gilbert and Smiley 2004; Nicolotti et al. 2003; Wang et al. 2005; Wang and Allison 2008; Kazemi-Najafi et al. 2009), as shown in Table 1. Tree species included in the sample were tulip poplar (Liriodendron tulipifera), red maple (Acer rubrum), American elm (Ulmus americana), paulownia (Paulownia tomentosa), sycamore (Platanus occidentalis), ash (Fraxinus spp.), white oak (Quercus alba), American beech (Fagus grandifolia), white pine (Pinus strobus), white cedar (Thuja occidentalis), red oak (Quercus rubra), and black locust (Robinia pseudoacacia). We did not measure the density of our samples, but the species represented a wide range of wood densities (United States Department of Agriculture 2007).

The samples had the majority of their bark still intact and ranged in length from $58.4 \mathrm{~cm}$ to $221 \mathrm{~cm}$ and diameter from $32.5 \mathrm{~cm}$ to $99.1 \mathrm{~cm}$. The condition of each section was visually assessed and labeled as either "decayed" (having visible decay or hollows) or "non-decayed" (solid) (Luley 2006). The test bed and example cross-sections are shown in Figure 1.

\section{Measurement Equipment}

The data collection system was composed of an accelerometer (PCB Piezotronics, Inc., Shear Accelerometer, Model 353B33) with a frequency range of 1 to $4,000 \mathrm{~Hz}$, a load cell hammer (PCB Piezotronics, Inc., Load Cell Hammer, Model 


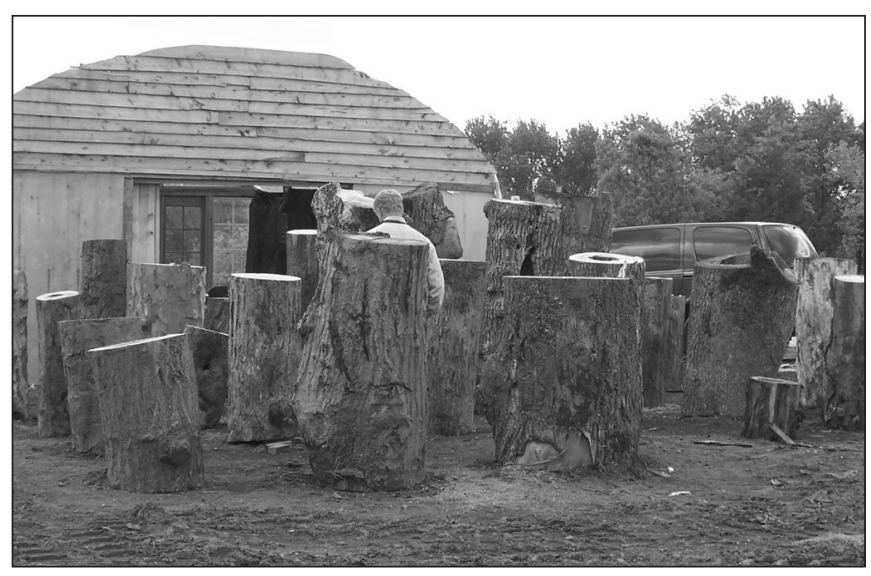

Figure 1a. Experimental test bed. Twenty recently felled tree specimens.

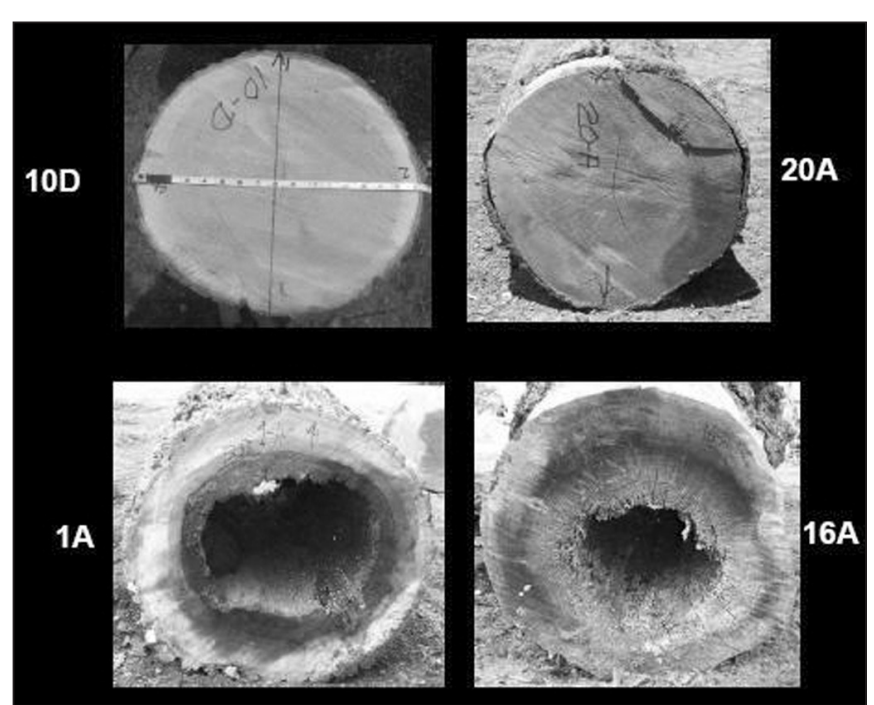

Figure 1b. Examples of specimens showing non-decayed (top) and hollow (bottom).

086D20), and a data acquisition module (Oros, Inc., 8-Channel Vibration Data Acquisition/Analyzer, Model OR35).

Nails were used to couple the vibration stress wave propagating through the trunk to the accelerometer; a $25.4 \mathrm{~mm}$ metal disk was tack welded onto wide-head nails so that each nail could be gently tapped through the bark to barely make contact with the underlying wood. The accelerometer was attached to the nail head using beeswax, a quick and wellbonded attachment procedure. The equipment is shown in Figure $2 \mathrm{a}$, and an example hammer strike is shown in Figure $2 \mathrm{~b}$.

\section{Measurement Procedure}

Each trunk sample was fitted with an accelerometer at the midpoint of the trunk's long axis, and the load cell and accelerometer were connected to the data acquisition module. The hammer was used to induce a stress wave at the same elevation as the accelerometer (along the trunk's long axis) but offset 45 degrees around the trunk's circumference (Figure 2a). When the operator struck the trunk with the hammer, the data acquisition hardware triggered an electronic recording of both the hammer strike's force over
Table 1. Sample identification and decay status for accelerometer testing.

\begin{tabular}{|c|c|c|c|}
\hline Sample ID ${ }^{z}$ & Tree Species & Decay Status & Diameter $(\mathrm{cm})$ \\
\hline $01 \mathrm{~A}^{y}$ & Tulip poplar & Decayed & 80.5 \\
\hline $01 \mathrm{~B}^{\mathrm{y}}$ & Tulip poplar & Decayed & 84.6 \\
\hline $02 \mathrm{~A}$ & Red maple & Decayed & 52.3 \\
\hline 02B & Red maple & Non-decayed & 43.2 \\
\hline $02 \mathrm{C}$ & Red maple & Non-decayed & 36.8 \\
\hline 02D & Red maple & Non-decayed & 34.3 \\
\hline $03 \mathrm{~A}^{\mathrm{y}}$ & American elm & Non-decayed & 73.9 \\
\hline $04 \mathrm{~A}$ & Paulownia & Decayed & 40.4 \\
\hline $04 \mathrm{~B}^{\mathrm{y}}$ & Paulownia & Non-decayed & 41.1 \\
\hline $04 C^{y}$ & Paulownia & Non-decayed & 46.5 \\
\hline $05 \mathrm{~A}$ & Sycamore & Non-decayed & 66.0 \\
\hline $05 \mathrm{~B}^{\mathrm{y}}$ & Sycamore & Non-decayed & 78.2 \\
\hline $06 \mathrm{~A}^{\mathrm{y}}$ & Ash & Decayed & 32.5 \\
\hline 06B & Ash & Decayed & 34.0 \\
\hline $07 \mathrm{~A}$ & Tulip poplar & Decayed & 61.5 \\
\hline $07 \mathrm{~B}^{\mathrm{y}}$ & Tulip poplar & Decayed & 58.7 \\
\hline $08 \mathrm{~A}$ & Red maple & Decayed & 40.4 \\
\hline $08 \mathrm{~B}$ & Red maple & Decayed & 35.8 \\
\hline $09 \mathrm{~A}$ & Tulip poplar & Decayed & 54.6 \\
\hline $10 \mathrm{~A}^{\mathrm{y}}$ & White oak & Decayed & 75.7 \\
\hline $10 \mathrm{~B}$ & White oak & Decayed & 56.1 \\
\hline $10 \mathrm{C}$ & White oak & Non-decayed & 52.1 \\
\hline $10 D^{y}$ & White oak & Non-decayed & 51.1 \\
\hline $11 \mathrm{~A}$ & Beech & Decayed & 56.1 \\
\hline $12 \mathrm{~A}$ & Sycamore & Decayed & 38.4 \\
\hline $13 \mathrm{~A}^{\mathrm{y}}$ & White pine & Decayed & 37.1 \\
\hline $14 \mathrm{~A}^{\mathrm{y}}$ & Cedar & Decayed & 37.6 \\
\hline $15 \mathrm{~A}$ & Tulip poplar & Decayed & 99.1 \\
\hline $16 \mathrm{~A}^{\mathrm{y}}$ & Red oak & Decayed & 98.3 \\
\hline $17 \mathrm{~A}$ & Red oak & Non-decayed & 76.5 \\
\hline $17 \mathrm{~B}$ & Red oak & Decayed & 62.0 \\
\hline $18 \mathrm{~A}$ & Black locust & Decayed & 38.1 \\
\hline $19 A^{y}$ & Red oak & Non-decayed & 68.6 \\
\hline $19 \mathrm{~B}^{\mathrm{y}}$ & Red oak & Non-decayed & 66.6 \\
\hline $20 \mathrm{~A}^{\mathrm{y}}$ & Tulip poplar & Non-decayed & 49.0 \\
\hline $20 B^{y}$ & Tulip poplar & Non-decayed & 50.5 \\
\hline
\end{tabular}

${ }^{\mathrm{z}}$ Sample IDs with the same numerical prefix were taken from the same sample. ${ }^{y}$ Indicates the samples that composed the training set: nine non-decayed and eight decayed segments.

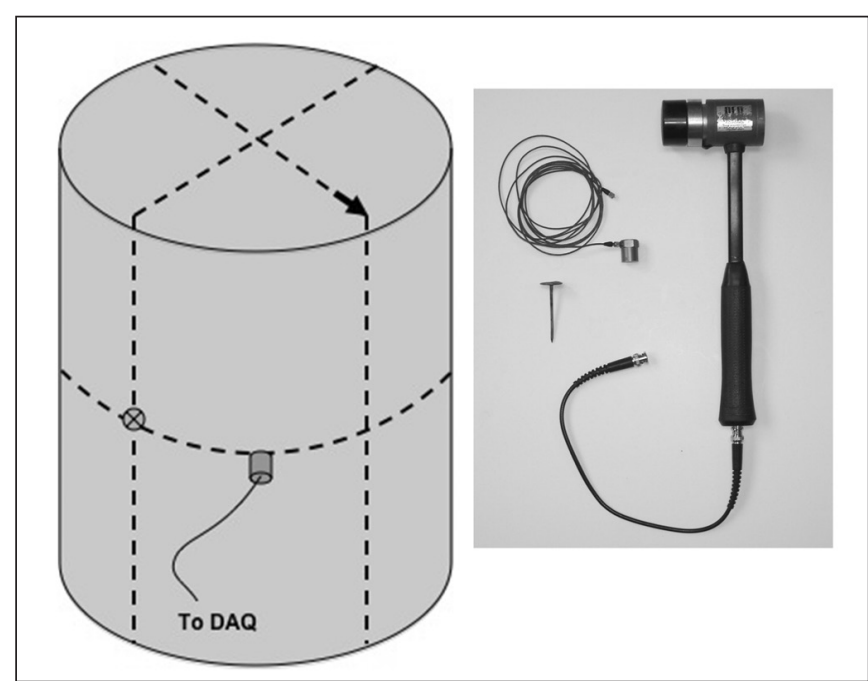

Figure 2a. Data collection setup. Instrumented tree sample, load cell hammer, accelerometer, and wide head nail. 


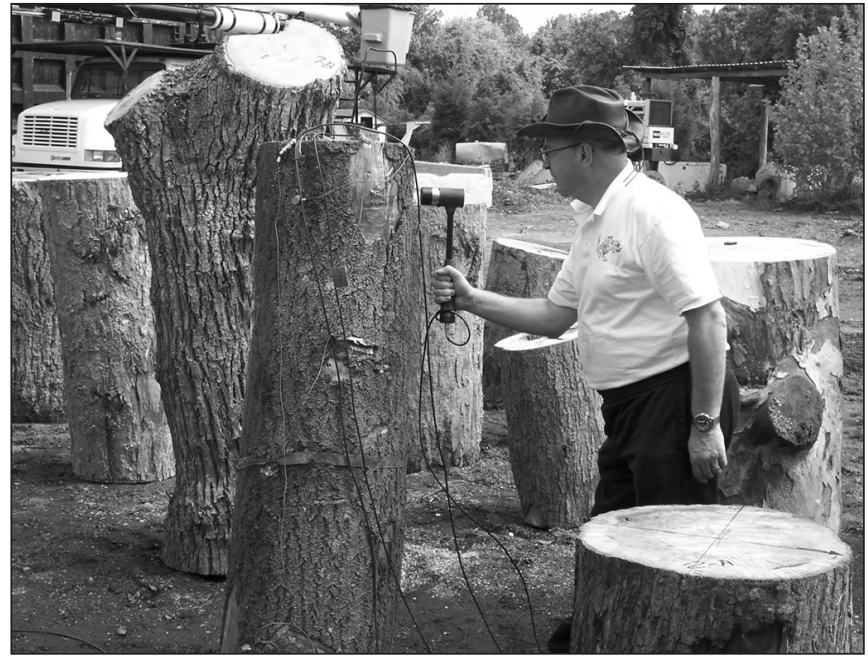

Figure 2b. Hammer strike.

time (i.e., the amount of energy induced by the hammer strike) and the response sensed by the accelerometer over time.

The load cell "force/response" recording was used to normalize the responses of the accelerometer channel to equalize input power across all tree samples as well as provide a quality assurance check on the hammer strike. A fairly gentle hammer strike was all that was required; if the strike was not hard enough, the data acquisition instrument issued an immediate alert to perform another strike. Four example waveform recordings are presented in Figure 3.

\section{DATA PROCESSING AND ANALYSIS}

The load cell hammer and accelerometer data were loaded into the MatLab (Ver. 7.3.0, R2006b, Natick, MA, U.S.) processing environment. The accelerometer signal was normalized by the strength of the hammer strike and rectified, and statistics were calculated that characterized the acoustic structure. A rules-based multivariate pattern classifier was developed that referenced these statistical features to automatically label each sample either decayed or non-decayed. These classifier labels were then compared against the actual conditions, assigned by the arborist, to assess the classifier's performance. The data processing analysis procedure is shown in Figure 4.

\section{Training and Testing Data Samples}

The classifier was developed using a set of calibration data (the training set of nine non-decayed and eight decayed specimens, as indicated in Table 1) such that the algorithm was provided with the correct answer for each waveform. The logic for classifying decay status was defined based on the waveform parameters of these calibration data to give the closest match between the predictions and the actual conditions. The full data set of all 36 samples shown in Table 1 was then used to check the classifier's ability to accurately and robustly predict the data conditions.

\section{Waveform Feature Extraction}

Twelve features were evaluated to distinguish the acoustic structure of the non-decayed and decayed samples, including the cumulative power of the conducted stress wave signal and 11
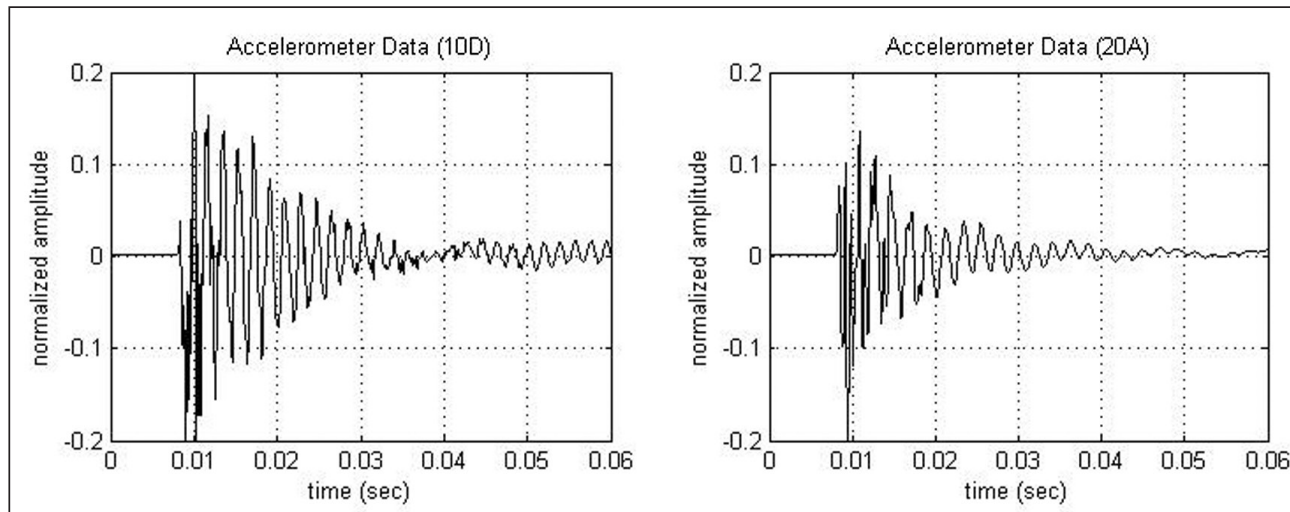

higher order statistics (Wellman and Srour 1999). Three features were found that best exploited waveform differences between the two decision categories.

1. Cumulative Power (aPower in Equation 1), computed as the cumulative sum of normalized data samples starting at initiation of the hammer strike, represents the amount of energy transmitted through the trunk. Large values tend to be associated with an internal decay that results in reverberations, which can lead to larger amplitudes of the recorded signal (larger total power) compared to a solid section that generally shows less total transmitted power.

2. Pulse Duration (PulseDur), computed as the amount of time the signal spends above a threshold (the half power points on either side of the signal peak), represents resistance of the trunk to stress wave transmission. Large values are associated with the presence of an internal hollow due to the longer-lasting reverberatory sequence creat-
Figure 3. Example waveform amplitude versus time plots for solid (top row) samples 10D and 20A and hollow (bottom row) samples $1 \mathrm{~A}$ and 16A, from which the three statistical waveform features were determined. 
ed by the hollow area, compared to a straight-through, shorter duration, time of transmission through a solid crosssection.

3. Amplitude Kurtosis (kurt ${ }_{a m p}$ in Equation 2), computed as a higher-order statistical descriptor of the waveform signal's amplitude shape and specifically the sharpness of the signal's peak, represents the extent of homogeneity of the internal trunk matrix. A signal with high kurtosis has a sharper peak and longer, fatter tails, while a low kurtosis signal has a more rounded peak and shorter, thinner tails. Larger values are associated with greater homogeneity and sound internal conditions because the vibration energy is transmitted quicker along a direct path to the receiver, whereas smaller values are associated with decayed samples because the energy is unfocused during propagation through the trunk. This is easily observed in Figure 3, where the majority of the energy in the sound samples is clustered near the impulse start as opposed to the significant long-duration low-frequency reverberation present in the decayed samples:

[1]

$$
\begin{gathered}
\text { aNorm }(i i)=\frac{a(i i)}{\sum_{i=1}^{N} h(i)} ; i i=I: N \\
\text { aPower }=\sum_{i=1}^{N} a \operatorname{Norm}(i) \\
\mu_{\text {amp }}=\frac{1}{N} \sum_{i=1}^{N} a(i) \\
\sigma_{\text {amp }}=\sqrt{\frac{\sum_{i=1}^{N}\left[a(i)-\mu_{\text {amp }}\right]^{2}}{N-1}} \\
\text { [2] } \text { kurt }_{\text {amp }}=\frac{1}{N}\left\{\left[\sum_{i=1}^{N}\left[\frac{a(i)-\mu_{a m p}}{\sigma_{a m p}}\right]^{4}\right\}-3\right.
\end{gathered}
$$

where $h(i)=$ amplitude signal of the hammer cell recording for each time sample ( $\mathrm{N}$ total samples); $a(i)=$ amplitude signal of the accelerometer for each time sample ( $\mathrm{N}$ total samples).

The distributions of the values from these three features across all of the training data set samples are shown in Figure 5. The plot shows that each feature captures a distinguishing characteristic of one data class with potential to separate it from other classes.

\section{Classification Methodology}

The classifier was configured to segment the statistical feature space based on the training data set, as shown in Figure 6. The study authors created classifier rules to maximize the separation between the decayed and non-decayed training samples. A sample was classified "non-decayed" if its three feature values satisfied one or both of the following requirements:

Classifier Rule $1=\left(\right.$ kurt $\left._{a m p}>1199\right)$ AND $\left(k_{\text {kurt }}{ }_{a m p}<2600\right)$

Classifier Rule $2=($ aPower $>1.13$ AND aPower $<27)$ AND $($ PulseDur $<3.14 \mathrm{e}-4)$

Otherwise, the sample was classified "decayed." These rules were applied to the full data set.

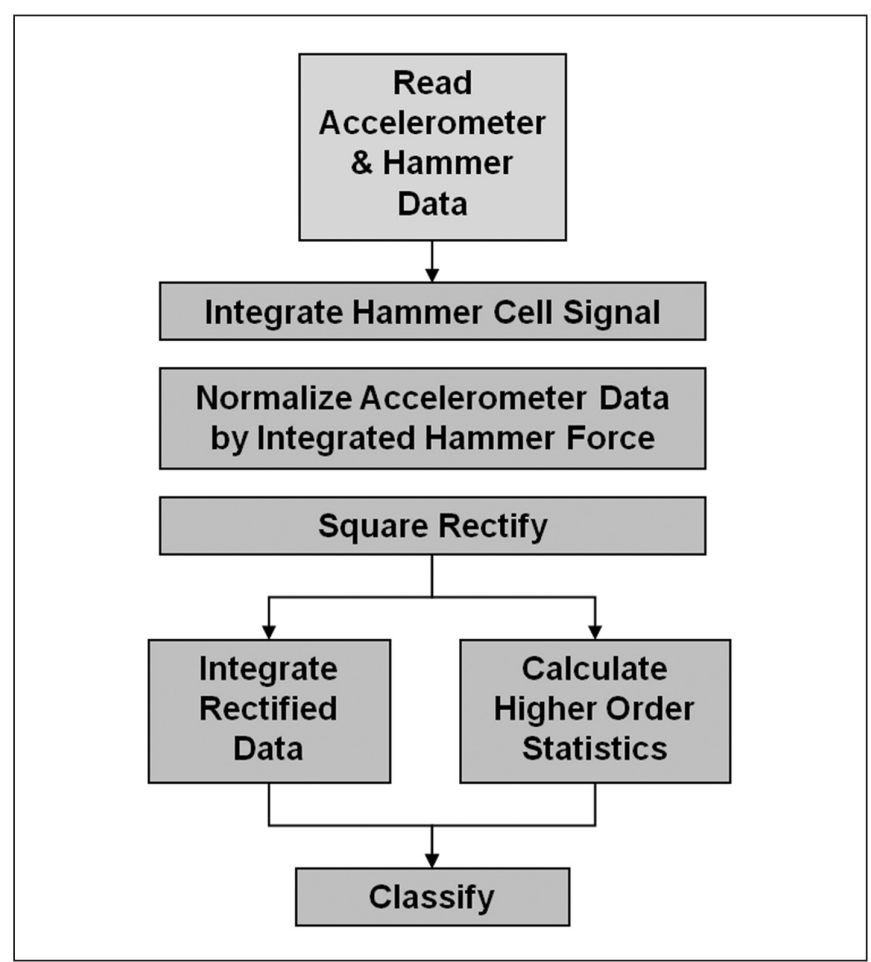

Figure 4. Data processing block diagram.

\section{RESULTS AND DISCUSSION}

Overall, the rules-based classifier correctly classified 30 of 36 $(83 \%)$ of the samples. Of the 15 non-decayed (sound) samples, 14 of $15(93 \%)$ were correctly classified as non-decayed. Of the 21 decayed samples (includes advanced decay and hollows), 16 of 21 $(76 \%)$ were correctly identified as containing decay, meaning that five were incorrectly predicted to contain solid internal conditions.

The $\chi^{2}$ statistics showed the classification results could not have happened by chance based on a 0.01 alpha level of significance $\left(\chi^{2}=18.7\right.$ with 1 degree of freedom) and that there was no significant difference between the expected classification and actual classifications for decayed and non-decayed samples $\left(\chi^{2}=0.65\right.$ with 1 degree of freedom). Plots of classifier result by trunk size and species (Figure 7) showed no apparent relationship between these parameters and classifier accuracy. This was true for the 30 correctly and six incorrectly $(8 \mathrm{~B}, 9 \mathrm{~A}, 10 \mathrm{~B}$, $10 \mathrm{C}, 11 \mathrm{~A}, 12 \mathrm{~A}$ ) classified samples. It is believed that the few incorrect classifications were due to the relatively small number of training samples and not the underlying approach given the lack of a pattern to the misses; the robustness of the approach will be validated in future tests with additional samples.

The $83 \%$ overall success rate was slightly better than the $74 \%$ correct identification result reported for the Axmon et al. (2004) system. These comparable results were achieved with a statistical classifier approach across numerous urban tree species and did not require recalibration for each new species, demonstrating the system's robustness and appropriateness for an urban application. Furthermore, the system relied on a simpler and more cost-effective assemblage of hardware. Axmon et al. (2004) measured percussive propagation velocity using multiple accelerometers, whereas the method presented here simply relied on aberrant characteristics of vibration waveforms measured using a single accelerometer. 


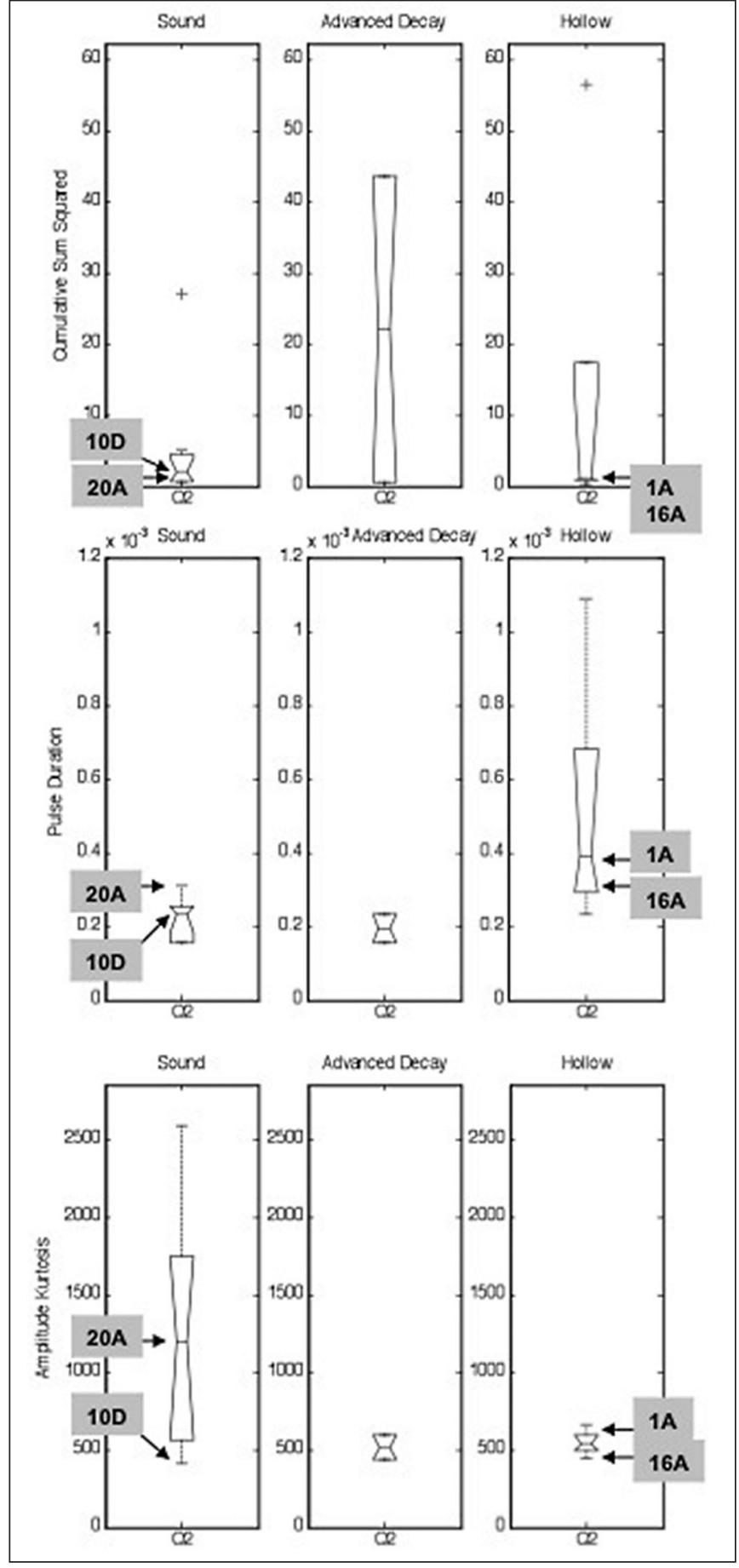

Figure 5. Box and whisker plots of the distributions of feature values for the sound, advanced decay, and hollow training data samples. The top row of plots shows Cumulative Sum Squared distributions, the middle row shows Pulse Duration, and the bottom row shows Amplitude Kurtosis. The horizontal mark in each box is the sample's median value and the edges of the box are the 25th and 75th percentiles. Values for solid samples 10D and 20A and hollow samples $1 \mathrm{~A}$ and $16 \mathrm{~A}$ are given for reference. Note: Advanced decay and hollow are both classified as "decayed" but are presented here individually.
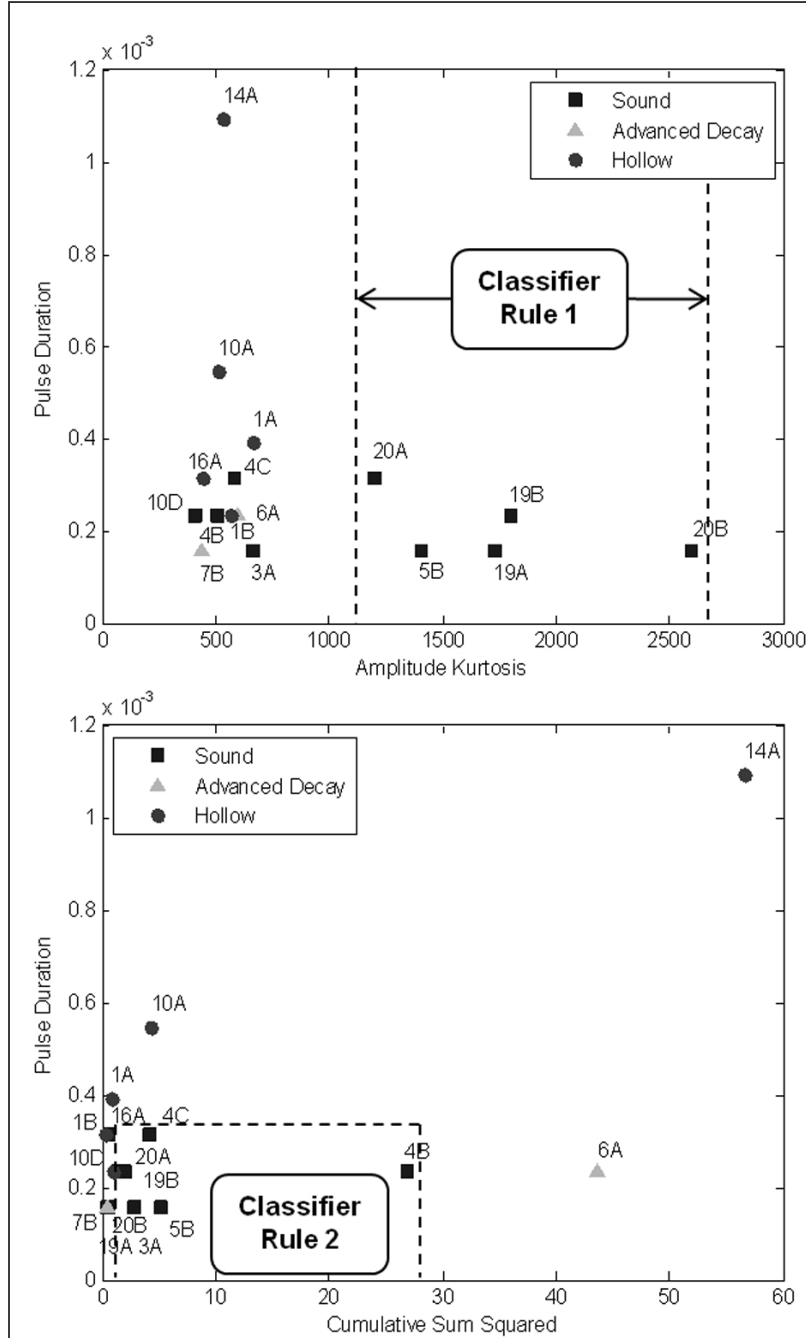

Figure 6. Scatter plots of the feature values for the sound, advanced decay, and hollow training data samples with the classifier regions demarcated by the shaded boxes. The classifier optimally segments the feature space and separates the decayed (advanced decay and hollow) and non-decayed training samples.

The work reported here was restricted to relatively short sections of recently cut tree trunks. The vibrational behavior of a trunk changes when a part is removed from the complete stem because removal reduces the compressional load. However, the authors believe the propagation effects induced by this unloading do not significantly impact results. The signal analyzed represents the initial arrival of the exciting pulse traveling a very short distance from the hammer to the accelerometer through the wood. Consequently, the difference between the boundary conditions for the sections and those for standing trees should have little effect on the statistical feature classifier. Future work using standing trees will be needed to verify the classifier's effectiveness.

The automated classifier likely successfully identified decay in the sample data because the features represented a statistically sufficient description of the waveform acoustic structure. The finding that several features were needed in combination to 


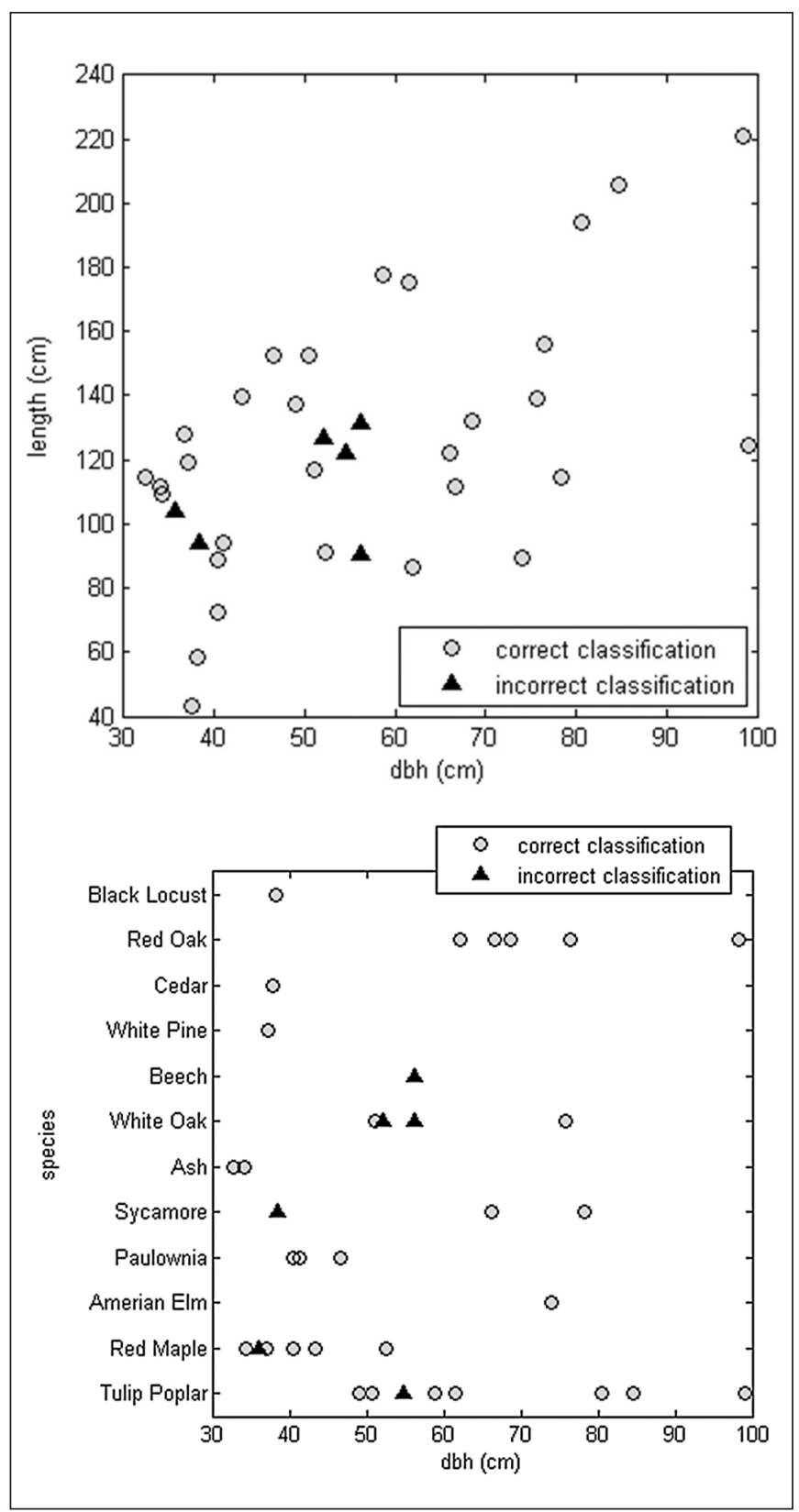

Figure 7. Distribution of all sample lengths, diameters, and species showing a lack of classifier bias. a) Distribution of trunk length versus diameter. b) Distribution of trunk species versus diameter.

separate the "decayed" and "non-decayed" classes was consistent with Lufti (2001), who showed that several acoustic parameters were necessary to aurally classify a hollow bar in laboratory conditions. The acoustic structures described by the three statistical features were also related to the acoustics used by arborists to classify the trunk segments with sounding: the characteristic "thud" sound of hollow trees is shown in Figure 3 as long-duration low-frequency reverberation (slow wave modulation in the sonic waveform) that is also reflected in the cumulative power, pulse duration, and amplitude kurtosis features.

\section{CONCLUSIONS}

The results of this feasibility study showed that classification based on several vibration waveform statistics was able to detect decay in trunk segments of a wide range of urban tree species. The authors believe this research establishes the feasibility of using an electro-mechanical instrument to replicate the trained human ear. This accelerometer system is a fundamentally different and novel concept in the context of existing velocity-based instrumented systems. Compared to a human operator, the advantages of the instrument are that it operates at a much higher sensitivity to frequencies of interest, does not lose its frequency discrimination over time, and is insensitive to ambient noise. If its application is as successful for standing mature trees as with the tested trunk segments, it has the potential for being used by arborists to identify trees that should be subjected to more detailed inspection.

This work provides only preliminary evidence that the method and protocol described herein may have value as an initial decay detection tool. The authors recognize there is a big step from this feasibility test to real world application involving standing trees, including various influences of trunk geometry, moisture, temperature, and material properties. Future work will focus on testing additional trunk samples, establishing the distance at which decay can be detected from the location of the hammer strike, and determining the effects of standing trees versus felled segments. Furthermore, the authors plan to construct an electro-mechanical complete system prototype for classifying samples in real-time on standing trees.

Acknowledgments. The authors wish to thank Mr. Pogo Sherwood (Pogo Tree Experts, Olney, MD, U.S.) for his expertise and help in locating and preparing the tree samples and for making his facilities available for our experimental data collection purposes. The authors also wish to thank Dr. Colin Ratcliffe (U.S. Naval Academy, Dept. of Mechanical Engineering, Annapolis, MD, U.S.) for providing the accelerometer data acquisition instrumentation and for his assistance in the field collecting data. The authors gratefully acknowledge the $A U F$ reviewers who greatly enhanced this paper with their constructive comments.

\section{LITERATURE CITED}

Axmon, J., M. Hansson, and L. Sörnmo. 2004. Experimental Study on the Possibility of Detecting Internal Decay in Standing Picea abies by Blind Impact Response Analysis. Forestry 77(3):179-192.

Ballas, J.A. 1993. Common Factors in the Identification of an Assortment of Brief Everyday Sounds, Journal of Experimental Psychology. Human Perception and Performance 19:250-267.

Boyce, J.S. 1961. Forest Pathology. 3rd Edition. McGraw-Hill Book Company, New York.

Brashaw, B.K., V. Bucur, F. Divos, R. Goncalves, J. Lu, R. Meder, R.F. Pellerin, S. Potter, R.J. Ross, X. Wang, Y. Yin. 2009. Nondestructive Testing and Evaluation of Wood: A Worldwide Research Update. Forest Products Journal 59 (37):7-14.

Bucur, V. 2003. Nondestructive Characterization and Imaging of Wood. Springer-Verlag, Berlin.

Bucur, V. 2005. Ultrasonic techniques for nondestructive testing of standing trees. Ultrasonics 43:237-239.

Fowler, C.A., and L.D. Rosenblum. 1990. Duplex Perception: A Comparison of Monosyllables and Slamming Doors. Journal of Experimental Psychology. Human Perception and Performance 16:742-754. 
Freed, D.J. 1990. Auditory Correlates of Perceived Mallet Hardness for a Set of Recorded Percussive Sound Events. The Journal of the Acoustical Society of America. 87:311-322.

Gilbert, E.A., and E.T. Smiley. 2004. Picus Sonic Tomography for the Quantification of Decay in White Oak (Quercus alba) and Hickory (Carya spp.). Journal of Arboriculture 30(5):277-280.

Howard Jr., J.H., and J.A. Ballas. 1980. Syntactic and Semantic Factors in the Classification of Nonspeech Transient Patterns. Perception and Psychophysics 28(5):431-439.

Howard Jr., J.H. 1977. Psychophysical Structure of Eight Complex Underwater Sounds. Journal of the Acoustical Society of America 62(1):149-156.

Kazemi-Najafi, S., A. Shalbafan, and G. Ebrahimi. 2009. Internal decay assessment in standing beech trees using ultrasonic velocity measurement. European Journal of Forest Research 128:345-350.

Li, X.F., R.J. Logan, and R.E. Pastore. 1991. Perception of Acoustic Source Characteristics: Walking Sounds. Journal of the Acoustical Society of America 90:3036-3049.

Lufti, R.A. 2001. Auditory Detection of Hollowness. Journal of the Acoustical Society of America 110(2):1010-1019.

Luley, C.J. 2006. Identifying wood decay and wood decay fungi in urban trees. Arborist News 15(2):12-19.

Mattheck, C., and H. Breloer. 1994. The Body Language of Trees: A Handbook for Failure Analysis. HMSO, London.

Mattheck, C., and K. Bethge. 1993. Detection of Decay in Trees with the Metriguard Stress Wave Timer. Journal of Arboriculture 19(6): 374-378.

Miller, M.H. 1994. Auditory Classification of Impact Transients. Ph.D. Dissertation, Department of Psychology, School of Arts and Sciences of the Catholic University of America.

Nicolotti, G., L.V. Socco, R. Martinis, A. Godio, and L. Sambuelli. 2003. Application and comparison of three tomographic techniques for detection of decay in trees. Journal of Arboriculture 29(2):66-78.

Repp, B.H. 1987. The Sound of Two Hands Clapping: An Exploratory Study. Journal of the Acoustical Society of America 81(4):100-1109.

Rinn, F. 1999. Method and Device for 3D Tomographic Investigating of Materials. U.S. Patent PCT/DE00/01467.

Shin, F.B., and D.H. Kil. 1996. Pattern Recognition and Prediction with Application to Signal Characterization. American Institute of Physics. Woodbury, NY.

Stearns, S.D. 1976. On Selecting Features for Pattern Classifiers. Proceedings of the Third International Joint Conference on Pattern Recognition, Coronado, CA.
United States Department of Agriculture. 2007. The Encyclopedia of Wood. Forest Service. Forest Service Products Laboratory. Skyhorse Publishing, New York

Vapnik, V. 1998. Statistical Learning Theory. John Wiley, New York.

Wang, X., and R.B. Allison. 2008. Decay Detection in Red Oak Trees Using a Combination of Visual Inspection, Acoustic Testing, and Resistance Microdrilling. Arboriculture \& Urban Forestry 34(1):1-4.

Wang, X., F. Divos, C. Pilon, B.K. Brashaw, R.J. Ross, and R.F. Pellerin. 2004. Assessment of decay in standing timber using stress wave timing nondestructive evaluation tools-A guide for use and interpretation. Gen. Tech. Rep. FPL-GTR-147. U.S. Department of Agriculture, Forest Service, Forest Products Laboratory, Madison, WI. 12 pp.

Wang, X., J. Wiedenbeck, R.J. Ross, J.W. Forsman, J.R. Erickson, C. Pilon, and B.K. Brashaw. 2005. Nondestructive Evaluation of Incipient Decay in Hardwood Logs. Res. Pap. FPL-GTR-162. U.S. Department of Agriculture, Forest Service, Forest Products Laboratory, Madison, WI. 11 pp.

Warren, W.H., and R.R. Verbrugge. 1984. Auditory Perception of Breaking and Bouncing Events: A Case Study in Ecological Acoustics. Journal of Experimental Psychology. Human Perception and Performance. 10:704-712.

Wellman, M., and N. Srour. 1999. Enhanced Target Identification Using Higher Order Shape Statistics. ARL-TR-1723. U.S. Army Research Laboratory, Adelphi, MD.

Zabel, R.A., and J.J. Morrell. 1992. Wood Microbiology: Decay and Its Prevention. Academic Press, New York.

Anthony N. Mucciardi, Ph.D. (corresponding author)

TreeRadar, Inc.

Silver Spring, MD 20910, U.S.

tony@TreeRadar.com

Christopher J. Luley, Ph.D.

Urban Forestry, LLC

Naples, NY 14512, U.S.

Kevin H. Gormally, Ph.D.

The Johns Hopkins University Applied Physics Laboratory Senior Professional Staff

Laurel, MD 20723, U.S. 
Résumé. Les arboriculteurs utilisent régulièrement le sondage sonore au cours d'une évaluation initiale d'arbres urbains pour déterminer la présence de zones de carie avancées et de cavités. Frapper le tronc avec un maillet produit des ondes sonores qui se propagent au travers du bois et en retour génèrent des sons caractéristiques et audibles. L'application correcte de cette procédure requiert malgré tout une évaluation subjective des variations sonores qui se produisent selon les différents types d'espèce de bois, leur densité et les conditions ambiantes de bruits. En conséquence, une approche de classification statistique a été développée pour automatiquement identifier une zone de carie à partir d'ondes sonores capturées au moyen d'une sonde d'accéléromètre qui est moins subjective et plus reproductive que l'approche humaine. Les algorithmes de classification ont été mis au point pour détecter la présence de carie par rapport aux caractéristiques aberrantes de vibration des formes d'ondes et ne dépendent pas des changements de vélocité des ondes sonores communément utilisés avec la plupart des test soniques de détection de la carie. Cette approche a été testée dans le cadre d'une étude préliminaire avec 36 échantillons de segments de tronc représentant une grande variété d'espèces urbaines typiques et de différentes caries. Le système de classification a permis d'identifier avec succès la présence de carie dans $83 \%$ des échantillons, et ce indépendamment de la l'espèce et du diamètre du tronc. Les résultats de cette étude de faisabilité ne peuvent être transférés directement dans le cadre réel d'inspections d'arbres sans l'apport de tests additionnels sur des arbres debout, mais ils démontrent l'utilisation potentielle des accéléromètres couplés à un système de classification statistique comme support de l'évaluation initiale de la carie chez les arbres urbains par un arboriculteur.

Zusammenfassung. Arboristen verwenden gewöhnlich ein Schallsystem während der ersten Bewertung von Strassenbäumen, um eventuelle Fäulen und Hohlräume aufzuzeigen. Das Beklopfen des Stammes mit einem Hammer produziert Wellen, die durch das Holz dringen und charakteristische, hörbare Geräusche verursachen. Eine erfolgreiche Anwendung erfordert allerdings eine subjektive Bewertung der Geräuschvarianzen, die aus unterschiedlichen Holzarten und Holzdichten resultieren, sowie verschiedene Umgebungsgeräusche. Daher wurde ein Versuch zur statistischen Klassifizierung entwickelt, um automatisch aus den mit einer Beschleunigungsprobe erzieltenStresswellen Faulstellen zu identifizieren, da diese weniger anfällig und besser reproduzierbar sind als andere Versuche. Die Algorithmen der Klassifikation sind ausgerichtet auf das Aufspüren von Fäule anhand von abweichenden Eigenschaften der Vibrationswellen und sind nicht abhängig von Veränderungen der Schallgeschwindigkeit, wie sie in den meisten anderen Schallsystemen verwendet werden. Der Versuchsaufbau wurde in einem Testlauf an 36 Stämmen, die eine große Auswahl an typischen urbanen Baumarten representieren und an deren Fäuletypen getestet. Der Klassifizierer identifizierte erfolgreich den Fäulestatus von $83 \%$ der Proben, unabhängig von Art oder Stammdurchmesser. Die Ergebnisse dieser Machbarkeits-Studie sind ohne weitere Testreihen an stehenden Bäumen nicht übertragbar auf richtige Baumkontrollen, aber sie demonstrieren das Potential für den Einsatz von Beschleunigungsmessern, die mit einem statistischen Klassifizierer ausgestattet sind, um die erste Untersuchung von Fäulnis in Bäumen durch Arboristen zu unterstützen.

Resumen. Los arboristas comúnmente usan el sonido durante una evaluación inicial de los árboles urbanos para determinar la presencia de descomposición avanzada y cavidades. Golpeando el tronco con un martillo se producen ondas de tensión que se propagan a través de la madera y, a cambio, generan sonidos audibles característicos. La aplicación exitosa de este procedimiento, sin embargo, requiere la evaluación subjetiva de las variaciones sónicas que resultan de las diferentes especies maderables y sus densidades, y diferentes ambientes de ruido. De allí que se desarrolló una aproximación de clasificación estadística para identificar automáticamente la descomposición de ondas de tensión capturadas usando una probeta con acelerómetro, que es menos subjetiva y más reproducible que un operador. Los algoritmos de clasificación fueron diseñados para detectar la presencia de descomposición de características de variación de forma de onda y hacer los cambios de velocidad de sonido comúnmente usado en la mayoría de las pruebas sónicas. La aproximación fue probada en un estudio preliminar de 36 muestras del tronco segmentadas representando un rango amplio de especies típicas urbanas y tipos de descomposición. El clasificador identificó exitosamente el estado de la descomposición de $83 \%$ de las muestras, independientemente de la especie de árbol y diámetro del tronco. Los resultados de este estudio no pueden transferirse al mundo real de la inspección de los árboles sin pruebas adicionales en árboles en pie, pero demuestran el potencial del uso de acelerómetros, suplementados con un clasificador estadístico para apoyar una evaluación inicial de la descomposición en árboles urbanos por un arborista. 